\title{
The death of a leader: Calvin commenting on Joshua in the last year of his life (1563)
}

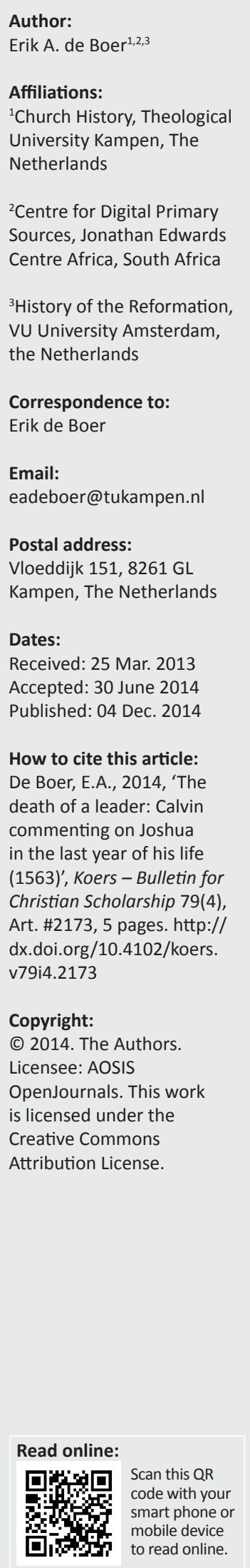

In the early modern period the testament, death, burial and funeral orations of public figures were often registered carefully. Such accounts told the story of the esteem in which the leaders were held, as the example of Martin Luther shows. While the account of John Calvin's demise seems simpler, in his case the story of his dying days is focused on his farewell addresses. The surviving manuscripts of Calvin's contributions to the Bible study of Joshua in 1563-1564 testify to his awareness of his mortality. How did he, their moderator, address the Company of Pastors in the course of their treatment of the book of Joshua in the weekly congrégations during the last year of his life? Both the end of the Pentateuch Harmony and the Joshua commentary cover farewell speeches of Israel's leaders. Did Calvin compare the Old Testament prophets and leaders with the preachers of Geneva? The academic discussion of Calvin's perception of himself as a prophet is taken up in the discussion of his self-awareness in the last year of collegial exposition of the Bible.

Die dood van 'n leier: Calvyn se kommentaar op Josua in die laaste jaar van sy lewe (1563). In die vroeë moderne periode is die testament, dood, begrafnis en begrafnistoesprake van openbare figure dikwels noukeurig opgeteken. Sulke verslae gee weer watter agting daar vir hierdie leiers was, soos die voorbeeld van Martin Luther duidelik aantoon. Ofskoon die verslag van Johannes Calvyn se afsterwe eenvoudiger lyk, fokus die verhaal van sy laaste dae veral op sy afskeidsredes. Die oorblywende manuskripte van Calvyn se bydraes aan die Bybelstudie oor Josua in 1563-1564 getuig hoe hy bewustelik oor sy eie sterflikheid gereflekteer het. Hoe het hy, hulle voorsitter, gedurende die laaste jaar van sy lewe die Vergadering van Predikante toegespreek tydens die behandeling van die boek Josua in die weeklikse congrégations? Sowel die einde van die Harmonie op die Pentateug as die einde van die kommentaar op Josua behandel afskeidsredes van Israel se leiers. Het Calvyn die Ou-Testamentiese profete en leiers met die predikante van Genève vergelyk? Die akademiese diskussie oor Calvyn se persepsie van homself as profeet is deel van die diskussie oor sy selfbewussyn in die laaste jaar van die kollegiale uitleg van die Bybel.

\section{Introduction}

If a person's life has come to an end, their final will and farewell will probably mirror their deepest convictions and public position in life. The burial of a Christian man or woman will testify to their faith of a life spent following Christ. Yet anthropologists and historians discern different rituals of death and burial, depending on time and place. When Martin Luther died in 1546 , his last words were recorded by Justus Jonas, no fewer than four commemorative sermons were held, and his body was transported in a tin coffin from Eisleben to Wittenberg. There he was buried in the Schlosskirche (Brecht 1987:370-375). Luther was regarded as the father of the Reformation, a public figure whose demise was immediately reported to the Elector Johann Friedrich, who ordered that he be buried in Wittenberg (not in Eisleben, as had been the wish of the Earl of Mansfeld).

Compared to Luther's burial, John Calvin's was rather poor. The mode of burial did not differ from the interment of ordinary citizens. Also, Calvin was buried in the public cemetery of Plainpalais, according to his last will 'that my body after my demise shall be interred in the customary manner, awaiting the day of the glorious resurrection' (CO 20, 298-302; nr. 4103). What does that imply? Having died around 18:00 on 27 May 1564, his body, covered in linen, was carried to the grave the very next day. No special service was held in church (apart from the usual morning service?), no sermon has been preserved and no memorial marked his grave on Plainpalais. Still, Calvin's dying days are well remembered, thanks to his testament, drawn up in the company of friends, and to the so-called 'Farewell Addresses' in which he addressed the assembled members of Geneva's Small Council on 27 April and the Company of Pastors on the following day. 
The present topic is the spin-off of a major project which resulted in two books, composed as a diptych. The project investigated the Genevan congrégation, which was the weekly gathering of all the ministers of Geneva and the surrounding villages to study a Bible book in lectio continua. On Friday morning they met and one of the colleagues presented an introductory exposition of the chapter at hand, while the others commented. The moderator, John Calvin, gave a summary at the end and closed the meeting with a prayer. In 2012 the monograph on the Bible expositions in these weekly congrégations in the 16th century (The Genevan School of the Prophets. The congrégations of the Company of Pastors and its influence in 16th century Europe). The sister volume, a critical edition of texts relevant to the congrégations, has recently appeared as COR VII/I. An important part of the edition is a remarkably complete series of twenty-three texts on Joshua, held in Geneva from June 1563 until January 1564, that is, during the last year of John Calvin's life. Even more surprising was the present author's discovery of another volume of transcripts of the same series of expositions on Joshua (De Boer 2012a:194-198). The recently discovered volume contained ten texts in unpolished transcription (ms.fr. 404), the other volume is a carefully written copy which may have been produced because of Calvin's death and the uncertainty of the posthumous publication of the commentary on Joshua. Both sets testify to the high value which Calvin attributed to the meetings of the Company of Pastors, especially during his final months.

The research question of this essay is: How did Calvin, in his role as moderator of the Company of Pastors, speak of preparation for death and the transference of leadership in the course of the exposition of Joshua? This question is related to academic discussions on whether or not Calvin saw himself as a prophet or was regarded by others as such. Theodore Beza's statement after Calvin's demise is well known: 'the city mourned the prophet of our Lord'. ${ }^{1}$ In recent scholarship the thesis has been advanced that Calvin staged circumstances around his 'series of farewell rituals' (Reeling, Brouwer \& Rinse 2004), that he gave himself the profile of a prophet, for example, by opting for an unmarked grave (Engammare 2002). Rhetorically, Calvin's use of the diminutive corpusculum ('poor body'), with adjectives as imbecillum ('weak'), in the letters of his later years would point to the Erasmian model of the suffering Hercules (Millet 2010). Did Calvin imitate the examples of leaders in the Bible, like Jacob or Moses, whose farewell words were recorded to us (Freudenberg 1997:284-286)?

\section{The ailing leader}

The dates of both Calvin's presence in and absence from the weekly Bible studies shed some light on his well-being between June 1563 and January 1564. As moderator he presented the first full exposition of the series on 04 June and was present at every Friday meeting until 13 August (on 20 August Beza replaces him and his concluding remarks are taken down). ${ }^{2}$ Then, until the end of October no meeting was recorded, apparently because of a period of illness. There was one exception, though: at the end of September, Calvin gave a full congrégation on Joshua 11. From the last days of October until the end of January 1564 he is present again (except for two absences). In the first week of February, Calvin's last sermon on 1 Kings and his very last lecture on Ezekiel are noted. The second half of August and September-October 1563 were thus hard on Calvin, as the letters testify. ${ }^{3}$ Yet, he was still not terminally ill.

Let us first proceed to read the history of the very last months as told by Theodore Beza and Nicolas Colladon in the various editions of the Vie de Calvin. The last months are described as follows. The old man still left the house in order to go to the congrégations on Fridays:

And he did this, as is quite probable, because there he was not obliged to speak for a full hour as in preaching or lecturing. He then only added, following the one who presented the exposition, what God had given him to say on the text that had been expounded, and spoke the exhortation to the prayer at the end of the session. (CO 21, 96)

Against the advice of his colleagues and family to stay inside, Calvin insisted on attending the study conferences because he said 'that he liked it, and time passed slowly, always sitting at home' (CO 21,97). ${ }^{4}$

In the description of the final months in the first two versions of the Vie de Calvin, the meetings of the Company of Pastors occupy an important place. On Fridays the colleagues, including those from the countryside, met and seized the opportunity to visit their sick friend. On 10 March some visiting colleagues found him in a remarkably good state, although he expressed the certainty that his final days were approaching. He often said: 'O Lord, how much longer?' (Seigneur, jusques à quand?). Two weeks later, Calvin was present at the last meeting of the Company of Pastors, dedicated to brotherly censure before the Easter celebration of the Lord's Supper..$^{5}$ The next Friday, 31 March, he was present in the Auditoire for the last time, 'a man all skin and bones' (CO 21, 160).

Calvin afterwards became so weak that he felt the time had come to say goodbye. He asked his fellow ministers 'from the city and the countryside' (the common expression for the members of the Friday meetings) to come to his house in the Rue des Chanoines. On Friday, 28 April he spoke his

2.See on Beza as acting moderator and his contributions to the Joshua series, De Boer (2012b, 2012c, 2012d).

3.Calvin's absence from the consistory meeting is registered until 11 November (CO 21,808 , with the exception of 30 September and 04 November; CO 21, 808). In that same week Calvin again made his appearance in the Council (CO 21, 809). At the end of September Bullinger expresses his compassion, having heard 'that other things have exhausted you and that you are burdened by even more unnumerable labors' (Bullinger to Calvin, 28 September 1563. CO 20, 162. ep, 4029). 'Recte labors' (Bullinger to Calvin, 28 September 1563; CO 20, 162; ep. 4029). 'Recte habet tota nostra schola, si Calvinus noster melius valaret, quem perpetui et varri Théodore de Bèze 4 ([1562-1563], 214).

4.'[...] mais il s'excusoit, disant qu'il y prenoit plaisir, et que le temps lui duroit trop se tenant tousjours en la maison.'

5.24 March 1564, see CO 21, 814. 
Discours d'adieu aux ministres (OS II, 401-404). ${ }^{6}$ Although this was his official farewell, the pastors all met once more. Three weeks later, on 19 May, the brotherly censure preceding the celebration of the Lord's Supper of Pentecost 1564 was held in the Rue des Chanoines (CO 21, 45, 168). They had a meal together to celebrate their friendship. This was his very last goodbye to the Company of Pastors as a body. John Calvin died on 27 May 1564 at the age of (only) 54. When one contemplates the facts recounted, it is clear that Calvin is portrayed in the company of his colleagues.

\section{Expounding on the Harmony of the Law and Joshua}

When the exposition of the harmony of the last four books of Moses in the congrégations was finished and the big book prepared for edition in Latin (1563) and French (1564), the ministers turned to the book of Joshua. They probably did so to accommodate Calvin in preparing his expository writing on the next Old Testament book. Still, the transcripts on Joshua include only two full expositions by Calvin, because he took his turn with the same frequency as his colleagues. His other 18 contributions are additions or concluding addresses presented by Calvin as moderator of the congregations (one congrégation is by Michel Cop, two additions by Beza, amounting to a total of 23 texts on Joshua). If Calvin was conscious of his approaching death, he may have seized the opportunity to address his brethren on the farewell of a leader.

The very survival of the transcripts testifies to the importance the colleagues attached to the series on Joshua. There is no other series of texts from the congrégations, since such transcripts seem to have been destroyed after the edition of a commentary. What is more, in the case of the congrégations on Joshua, not only one, but two distinct collections of transcripts remain (ms.fr. 40a \& 404), as reported above. All his colleagues had been witness to Calvin's larger or minor contributions to the series on Joshua and to the ups and downs in his health. Was there something special in the contents of the series which made the transcripts more valuable than just a trial run of another commentary? Was John Calvin aware of his own approaching death? In his expository work on the last four books of Moses and on Joshua Calvin encountered the death of leaders - the patriarchs, Aaron and Moses (Dt 31-34), Eleazar and Joshua. These expositions were delivered orally in the bosom of the Company of Pastors. How did John Calvin address matters of dying and burial?

\section{The office of prophet and preacher}

Expounding on the book of Joshua, Calvin often dwells on the fact that, although God's promises are very liberal, we may have to wait long and hard for their fulfilment (e.g. f. 115b-116a, 137b-138a). ${ }^{7}$ To explain this, Calvin will

6 .Colladon dates this to 20 April (CO 21,43 ), but the contents suggest 28 April (cf. Beza, CO 21, 166f.)

7.The folio numbers refer to manuscript français $40 \mathrm{a}$ and can easily be traced in COR VII/I. refer to the necessity of a Saviour and point to David, who would be Israel's king and the forefather of Jesus Christ (f. 138b). In application, Calvin will point to the fact that most promises that seem to pertain to this mortal life are not fulfilled in it. The land of Canaan is as a mirror of all God's gifts towards his church. The blessings of the Promised Land in the old covenant therefore primarily point to the times 'when we shall come into the enjoyment of the eternal heritage' (f. 131b). In the closing prayer, Calvin asks that:

even though we are pilgrims in this world, that we can still enjoy the goods he gives us and which are there to make us long for that eternal heritage which he will let us taste in the eternal kingdom.

Looking for references to death and burial, I studied the full congrégration on Joshua 11, held in the middle of that long period of absence in the summer of 1563 . The chapter as such does not promise much occasion to address our theme, since it deals with the occupation of the north of the Promised Land. Calvin dwells especially on verse 6, where God addresses Joshua and assures him of victory. He comments:

But today we do not receive revelations from heaven. God will not send angels to us in order to make his will known, but we have his Word, we have his Law and his Gospel. (f. 117b)

Calvin thus turns the element of special revelation in the text into an address on the task of preachers today:

Let us direct therefore all our energy there, both night and day, that we may learn so to refresh the memory of God's promises that when our enemies will come to batter us, they never take us unaware [...].

Calvin also points out that God did not address Joshua for his own sake:

but it was for the instruction of the people. And that is how it is today when they who are best trained in his Word, should be as teachers to fortify the others. For when we have this task and office (charge et office) of teaching, that is not meant only that each applies to his own benefit what teaching (doctrine) he received, but that everybody benefits. And when God has spoken to those who have received a much greater blessing (grace) of his Spirit, it shall be for the general edification of the whole Church.

The office of the Word as gift of the Spirit is always in Calvin's mind.

The last verse of Joshua 11 states that Joshua conquered the whole land, as God had commanded Moses to do. Calvin comments: 'Thus Moses had carried out his duty as a good teacher by instructing his pupil which he had been assigned to him by God' (f. 120a). Again Calvin applies the message to the assembled ministers:

From this we have to remember that when God has given us the task to instruct the others, that we must do all that is possible to prepare them well, so that after our death (après nostre trespas) they know how to behave, and that each puts this into practise according to his level and position (degré et estat). Not all will be called as Moses to be a prophet for God, but some have the task to teach in public, while others have children [to teach], others have servants and chambermaids. (f. 120b) 
The fact that Moses, handing over his office to Joshua, is mentioned in verse 23 gave Calvin the opportunity to think of his own approaching death and to address his colleagues.

Having commented on Joshua 21, the special cities for the Levites, Calvin invites his colleagues to prayer:

in order to confirm and strengthen us more and more until we will be enjoying that eternal life to which we are dedicated every day. And that meanwhile we shall be intend to serve God, who has put us in this world, in such a way that when we shall be called before his seat of judgment, we will be able to render account before him that we have walked here in his obedience [...] (f. 139b)

Following the invitation to prayer, in which the Bible chapter is summarised, the closing prayer of the congrégation always proceeds with the formular passage of prayer for the church in oppression in France.

Chapter 23 contains Joshua's farewell speech. The congrégation of 17 December 1563 had been presented by the young assistant preacher, Jacques Des Bordes (De Boer 2012a:64-66, 219). His exposition was not taken down in writing; only Calvin's summaric statements (sommaire) were. The older man started as follows:

We have here a remarkable example that they who have served God and whom he has used and by whom he took care in a mighty way, should make sure (where they approach their death) that his service remains always intact and that the matters which they have put on the right track, continue (with following reference to St. Peter's testament in his second Letter).

This notion can also be heard in Calvin's farewell address to his colleagues (Discours d'adieu). The loss of their leader may result in chaos (cf. f. 142a):

Here is Joshua who had completed his course and his whole life. He has not stopped to acquit himself faithfully of his job. Seeing that his demise is close by, he ponders that it is much more necessary than ever that the people be exhorted and he provides as much as possible that after his death things will always proceed properly. Here is a point: that we should not only care for our times and that we do not care what will happen when we will be dead, but that the zeal and dedication which we have to serve God, extends until our death and to all posterity. (f. 141b; see also Moehn 2004:300f.)

Des Bordes may also have addressed the character of Joshua's farewell address, but Calvin feels the need to touch upon this aspect and apply it to the ministers, whose moderator he is in their communal expository exercise.

When Joshua states that he 'is about to go the way of all the earth' (23.14), Calvin launches into an admonition: we may very well speak of our mortality and that we cannot escape death as ordained, but the actual death of a loved-one often leads to mourning as if we had not expected him or her to die (f. 146b). But our life is a passage, as expressed in Psalm 90, verse 3:
Let us therefore realize that death is the way of all the earth, so that we may learn to console ourselves especially by the hope which he has given us.

\section{Death of a prophet?}

Beza's eulogy upon Calvin's death, 'For the body of the city mourned the prophet of the Lord,' has evoked some reflection among scholars. Did Calvin see himself also as a prophet of God? (cf. Engammare 1998). Was his farewell speech to his colleagues intended to hint at the speeches of the dying patriarchs Isaac and Jacob, and of Moses? Plato styled the farewell address of Socrates; Tacitus did the same for Seneca (cf. Freudenberg 1997:284f.). With regard to Calvin's funeral, Max Engammare has drawn attention to the plainness of the burial of ministers in the age of the Reformation in Geneva. The mode of burial did not differ from the interment of ordinary citizens. John Calvin, too, was buried in the public cemetery of Plainpalais according to his last will that my body after my demise shall be interred in the customary manner, awaiting the day of the glorious resurrection' (CO 20, 298-302; nr. 4103). Did the ministers of Geneva, and Calvin in particular, somehow imitate the example of the Old Testament prophets whose graves are unknown?

Engammare drew attention to Calvin's handwritten gloss in his copy of Chrysostom's Opera, written in the margin of a sermon on Jacob's burial (Gn 50). Calvin underlined the sentence 'Truly, we do not know where the prophets and apostles are laid to rest, with a few exceptions'. Calvin glossed, probably in his early years: 'On pompous tombs' (De sumptuosis sepulturis) (Ganoczy \& Müller 1981:92; Engammare 2002:289). This locus-like heading does not return in his works, but the theme occupied his thoughts in expounding the last chapter of Deuteronomy on the deaths of Moses (as already announced in the outline of the Mosaic Harmony, given in the introductory congrégation), Joshua and Eleazar (Jos 24). Was Calvin buried 'in the sober way of an Old Testament prophet, of Moses himself, with the Genevan practice in line with his prophetic aspirations'? (Engammare 2002:290)

From Calvin's testament it is clear that he wanted to be buried without any distinction. ${ }^{8} \mathrm{He}$ did not, however, expressly ask for an unmarked grave. Commenting on the death and burial of Moses, he stressed that God did not spare 'his excellent prophet' the shame of death outside the Holy Land. The specifics of Moses' burial are explained as a clear testimony of God's direct involvement in taking care of the body of his servant. 'He was buried by divine power, for it is said that his grave remained unknown' (CO 25:399). Calvin ended his exposition of the verses on Moses' death and burial, and Israel's mourning, by commenting on the ceremonial aspects and stating the general rule. The ceremonial number of (thirty) days of mourning, so Calvin writes, is abrogated. 'Therefore, today the deceased are so to be buried that the hope of the resurrection, so clearly visible in Christ's coming, tempers our mourning' (CO 25:400).

8.Cf. Calvin's comments on the women's gifts at Jesus' burial in COR V/Vili, $172 \mathrm{f}$. 
In the congrégation on the final verses of Joshua 24 the Company must have dwelled on the death and burial of Joshua and Eleazar. In the comments which Calvin added to this discussion he dwelt briefly on the interment of the bones of Joseph in Sjechem. On the basis of Acts 7.15-16 he assumed that the remains of all twelve patriarchs were transported and buried in the Promised Land:

Every tribe had taken care of the bones of their first father. That is how the bones of the twelve patriarchs were brought into this promised heritage, although that is not stated specifically. (Ms.fr. 40b, f. 158a)

It was only in the closing prayer of that Friday morning, 14 January 1564, that Calvin alluded to cavern graves or tombstones. The prayer begins with the formulary lines, followed by specific petitions in which the biblical exposition echoes:

While we do not have a memorial, made of stone, to be erected today, let it suffice us that our Lord Jesus Christ shows us that he is the image of God, his Father, that is that he shows continuously when he is preached to us in the Gospel and his blood must flow before our eyes in order to be confirmed in the faith which we have received by his truth. Let us therefore never depart from this and walk reverently so that we serve him purely, without superstition and syncretism, nor being averted. Let us so live in this world that we always look at the heavenly life and let the burial (la sepulture) of those who died and die before us and of ourselves always serve us to confirm us in the hope which is given to us of the glory, in which we will be received in order to be made part of that heavenly heritage, so costly acquired for us. (Ms.fr. 40b, f. 158b)

The first line indicates that tombstones were not placed on the graves of reformed Geneva during the 16th century. Theodore Beza's funeral marked a departure from burial rites. In 1605 he received both a grave in the old cloister of St. Pierre and a memorial stone.

In the end, John Calvin and his colleagues did not advertise their Bible study as prophecy or identify this institution with the Israelite school of the prophets. If Calvin compared himself to a biblical prophet, it was in the sense not of holding an office but more of having worn a mantle since the early days of the Reformation of Geneva. The active involvement in expounding Scripture in daily sermons, regular lectures, and weekly congrégations brought the expositors in close proximity to their colleagues of old, the prophets and teachers of the Scriptures. ${ }^{9}$ John Calvin was very much aware of being in a leading position as expositor

9.Jon Balserak proposed to explain Calvin's image as he regarded himself as an authoritative interpreter of Scripture and as a reformer (Balserak 2011:65-108) authoritative interpreter of Scripture and as a reformer
Balserak (2014) appeared after this essay was completed. of Scripture, and that is what he taught about prophecy in the Church of his Lord.

\section{Acknowledgements Competing interests}

The author declares that he has no financial or personal relationship(s) that may have inappropriately influenced him in writing this article.

\section{References}

Balserak, J., 2011, Establishing the remnant church in France: Calvin's lectures on the minor prophets - 1556-1559 [Brill's Series in Church History 50], Brill, Leiden/ Boston. http://dx.doi.org/10.1163/ej.9789004191440.i-224

Balserak, J., 2014, John Calvin as sixteenth-century prophet, Oxford University Press, Oxford. http://dx.doi.org/10.1093/acprof:oso/9780198703259.001.0001

Brecht, M., 1987, Martin Luther, III Die Erhaltung der Kirche 1532-1546, Calwer Verlag, Stuttgart.

Calvin, J. 2011, 'Plusieurs sermons de Jean Calvin', (edidit) W.H.Th. Moehn in Auspiciis Praesidii Conventus Internationalis Studiis Calvinianis Fovendis ediderunt Auspiciis Praesidii Conventus Internationalis Studiis Calvinianis Fovendis ediderunt 't, loannis Calvini opera omnia: Denuo recognita et adnotatione critica instructa 't, loannis Calvini opera omnia: Denuo recognita et adnotatione critica instructa
notisque illustrata, Droz, Genève. (Series V: Sermones, Vol. VIII) [= COR V/VIII.]

Calvin, J. 2014, 'Congrégations et disputations', (edidit) E.A. de Boer in Auspiciis Praesidii Conventus Internationalis Studiis Calvinianis Fovendis ediderunt I. Backus, M. Engammare, H. Feld, F.M. Higman, W. Janse, A.N.S. Lane \& W. van 't, Ioannis Calvini opera omnia: Denuo recognita et adnotatione critica instructa notisque Calvini opera omnia: Denuo recognita et adnotatione critic
illustrata, Droz, Genève. (Series VII: Varia, Vol. I) [= COR VII/I.]

CO Ioannis Calvini Opera Quae Supersunt Omnia, 1863-1900, W. Baum, E. Cunitz, E. Reuss (eds.), 59 vols., Brunswick, Berlin,

De Boer, E.A., 2012a, The Genevan School of the Prophets. The Congrégations of the Company of Pastors and its influence in 16th century Europe [Travaux d'Humanisme et Renaissance 512], Librairie Droz, Geneva.

De Boer, E.A., 2012b, 'Beza als moderator van de Compagnie des Pasteurs', in W. Balke, J.C. Klok \& W. van 't Spijker (eds.), Théodore de Bèze: Zijn leven, zijn werk, pp. 134-136, 452, Kok, Utrecht.

De Boer, E.A., 2012c, 'Théodore de Bèze: Wat is wijsheid: Veilig thuis of in gevaar onderweg?', in W. Balke, J.C. Klok \& W. van 't Spijker (eds.), Théodore de Bèze: Zijn leven, zijn werk, 137-139, Kok, Utrecht.

De Boer, E.A., 2012d, 'Théodore de Bèze: Oordeel over Achan: Zachtheid in strengheid', in W. Balke, J.C. Klok \& W. van 't Spijker (eds.), Théodore de Bèze. Zijn leven, zijn werk, Kok, Utrecht, 140-143.

Engammare, M., 1998, 'Calvin: A prophet without a prophecy', Church history: Studies in Christianity and Culture 67(4), 643-661. http://dx.doi. org/10.2307/3169846

Engammare, M., 2002, 'L'inhumation de Calvin et des pasteurs Genevois de 1540 à 1620 . Un dépouillement très prophétique et une pompe funèbre protestante qui se met en place', in J. Balsamo (ed.), Les funérailles à la Renaissance, pp. 271-293, Librairie Droz, Geneva.

Freudenberg, M., 1997, 'Calvins Abschiedsreden (1564)', in E. Busch, A. Heron, Chr. Link, P. Opitz \& H. Scholl (eds.), Calvin Studienausgabe: Gestalt und Ordnung der Kirche, vol. 2, pp. 281-303, Neukirchner Verlag, Neukirchen.

Ganoczy, A. \& Müller, K., 1981, Calvins handschriftliche Annotationen zu Chrysostomus: Ein Beitrag zur Hermeneutik Calvins [Veröffentlichungen des Instituts für europäische Geschichte Mainz 102], Franz Steiner Verlag, Wiesbaden.

Millet, O., 2010, 'Calvin als Leidensmann: Berufung, Arbeit, Krankheiten', in H.J. Selderhuis (ed.), Calvin - Saint or Sinner?, pp. 50-65, Mohr Siebeck, Tübingen.

Moehn, W.H.Th., 2004, 'Abraham - "Père de l'Église de Dieu"', in H.J. Selderhuis (ed.), Calvinus Praeceptor Ecclesiae. Papers of the International Congress on Calvin Research, Princeton: August 20-24, pp. 287-301, Librairie Droz, Geneva.

OS Ioannis Calvini Opera Selecta, 1926-1936, 5 vols., P. Barth \& W. Niesel (eds.), Kaiser, Münich.

Reeling Brouwer, R.H. \& Rinse H., 2004, 'The memorial stone Calvin made for himself', in P.N. Holtrop, F. de Lange \& R. Roukema (eds.), Passion of Protestants, pp. 7-25, Kok, Kampen. 